\title{
A Force to be Reckoned with? The Radical Left in the 1970s.
}

La gauche radicale britannique dans les années 1970 :un acteur majeur?

Jeremy Tranmer

\section{(2) OpenEdition}

\section{Journals}

Electronic version

URL: http://journals.openedition.org/rfcb/1728

DOI: $10.4000 /$ rfcb. 1728

ISSN: 2429-4373

\section{Publisher}

CRECIB - Centre de recherche et d'études en civilisation britannique

\section{Electronic reference}

Jeremy Tranmer, «A Force to be Reckoned with? The Radical Left in the 1970s. », Revue Française de Civilisation Britannique [Online], XXII- Hors série | 2017, Online since 30 December 2017, connection on 01 May 2019. URL : http://journals.openedition.org/rfcb/1728; DOI : 10.4000/rfcb.1728

This text was automatically generated on 1 May 2019.



Revue française de civilisation britannique est mis à disposition selon les termes de la licence Creative Commons Attribution - Pas d'Utilisation Commerciale - Pas de Modification 4.0 International. 


\title{
A Force to be Reckoned with? The Radical Left in the 1970s.
}

\author{
La gauche radicale britannique dans les années 1970 :un acteur majeur?
}

\author{
Jeremy Tranmer
}

1 The rise to national prominence of Labour leader Jeremy Corbyn has been accompanied by allegations of sections of the radical left infiltrating and influencing the Labour Party. Trotskyists, in particular, have been accused of being active in the Momentum movement that supports Corbyn. ${ }^{1}$ In fact, this type of accusation is hardly new. Since the Russian Revolution, a number of parties and groupings have existed to the left of the Labour Party. Most of them share several basic characteristics. They are in favour of creating a revolutionary party to lead the working class in the class struggle rather than to represent it in parliament; they believe in the necessity of a revolutionary break with the existing economic and political order since piecemeal reform is deemed to be insufficient; they advocate replacing the private ownership of the means of production by collective ownership and creating participatory forms of political organization, such as workers' councils, to replace parliamentary democracy. These positions are based on interpretations of the writings of Marx, Lenin or Trotsky. The fortunes of the radical left have suffered because of the political dominance of the Labour Party, which has an organic link with the working class via the trade union movement, and because of the electoral system, which limits the chances of candidates belonging to small parties being elected to parliament or to local councils. The radical left has also been handicapped by the lack of a strong revolutionary tradition in Great Britain and by its own political instability.

2 In the late 1960s and 1970s, the radical left was more visible than it had been in previous decades, leading to 'red scares' in the press and in pamphlets. ${ }^{2}$ The Communist Party of Great Britain, which had appeared to be in terminal decline, experienced an "Indian summer" thanks to its work in the trade unions ${ }^{3}$, while the International Socialists/ Socialist Workers Party were active in rank and file organizations and came to the fore in the anti-fascist movement. This article will attempt to determine the extent to which parties to the left of Labour were a significant force in Britain in the 1970s. To do so, it 
will firstly present the main parties of the radical left, before examining their role in industrial disputes, their participation in extra-parliamentary campaigns and their involvement in other activities, including election campaigns.

\section{History and characteristics of the radical left}

3 In the 1970s, as in other periods of its history, the radical left was far from being homogeneous and was composed of a large number of relatively small organizations. This brief presentation will focus on the Communist Party of Great Britain (CPGB), the largest party to the left of Labour, and the main Trotskyist organizations of the time, the International Socialists (IS)/Socialist Workers Party (SWP), the International Marxist Group (IMG) and the Workers Revolutionary Party (WRP). ${ }^{4}$

4 Founded in 1920, the CPGB began to grow following its participation in the 1926 general strike but lost members during the 'Class Against Class' period of the late 1920s and early 1930s, when it adopted a highly sectarian approach to reformists in the labour movement. This was the first of several abrupt changes in line imposed by the Soviet Union. Its fortunes improved when, in 1935, it adopted the Popular Front strategy of broad cross-class alliances. It was at the heart of solidarity actions in defence of the Spanish Republic and of mass protests against British fascists. ${ }^{5}$ During the war, it benefited from the new-found popularity of the Soviet Union, its membership reaching an all-time high of 56,000 in $1942 .{ }^{6}$ Most members were integrated into local branches, but the party also had a network of factory branches. It achieved its best ever election results immediately after the war, gaining two MPs and over 200 local councillors.

With the onset of the Cold War, the CPGB adopted an increasingly hostile attitude to the Labour government. At the same time, it emphasized its national credentials, as exemplified by the adoption in 1951 of the first version of its long-term programme, the British Road to Socialism (BRS). ${ }^{7}$ The BRS signalled a move away from Leninism as the party envisaged radical change coming about as a result of the combination of parliamentary and extra-parliamentary agitation. The events of 1956 - the twentieth congress of the Soviet Communist Party denounced Stalin's crimes, and several months later the Soviet Union invaded Hungary to prop up the Communist regime - dealt a serious blow to the CPGB. The leadership reacted by limiting debate and stifling dissent in the party, but an estimated third of the membership resigned in protest. The CPGB managed to limit its decline and break out of its isolation in the following years by seeking unity with the nonCommunist left in the labour movement ${ }^{8}$ and organizing rank and file union activists in the Liaison Committee for the Defence of Trade Unions (LCDTU). In doing so, it made ample use of its daily newspaper, the Morning Star (previously the Daily Worker).

In the 1970s, the CPGB was involved in a myriad of campaigns, but its membership continued to fall. In 1969, it stood at just over 30,000, but it had dropped to 20,000 by 1979. This was partly the result of growing divisions within the party, particularly in the second half of the decade. They reached a peak in 1977 during discussions over the latest version of the BRS. Controversially, the new programme was influenced by Gramscian ideas and incorporated social movements such as feminism. On the eve of the congress, up to a thousand traditionalists left the CPGB, accusing it of revisionism, and founded the New Communist Party. ${ }^{9}$ In the 1980s, internal conflict intensified and spread to questions of theory, strategy and activity, engulfing the party, which officially ceased to exist in $1991 .^{10}$ 
7 Trotskyist organizations first appeared in Britain in the 1930s and 1940s. The largest was the Revolutionary Communist Party (RCP), which was founded in 1944 but rapidly became a victim of the factionalism that has dogged Trotskyism in Britain and elsewhere. It is significant because "[t]he fragments which emerged from its break-up eventually became the [...] principal tendencies of British Trotskyism". ${ }^{11}$ Following the demise of the RCP, most Trotskyists decided to work within the Labour Party, and were temporarily united in the early 1950s in a grouping called The Club, which was for a short time the official British representative of the Fourth International. ${ }^{12}$ However, it only had a few hundred members. Working within the Labour Party ('entryism') became a regular practice for many Trotskyists as it gave them an opportunity to spread their ideas and convert other Labour activists. Moreover, some believed that a severe economic crisis would inevitably occur and that workers would turn to the most radical sections of the Labour Party.

"Prior to 1956, the CPGB had dominated the political field to the left of the Labour Party", but the events of that year had weakened it and opened up a new space. ${ }^{13}$ One of the most distinctive currents that appeared in the 1950s was led by Tony Cliff, who had adopted an original analysis of the Soviet Union and the post-war boom in the West. ${ }^{14}$ According to Cliff, the Soviet Union was not a degenerated workers' state, as other Trotskyists claimed, but was a state capitalist country. The Stalinist bureaucracy had become a new ruling class which had slowly uprooted all traces of workers' power in the country. The Soviet Union functioned like a capitalist company, in which workers were exploited by the bureaucracy and which was in competition with other companies in the world economy. Cliff also suggested that post-war prosperity in the West was due to government spending on arms and what he and others termed 'the permanent arms economy'. He therefore refused to take sides in the Cold War and developed the slogan 'Neither Washington nor Moscow, but international socialism'. In 1962, Cliff's grouping became the IS and left the Labour Party three years later.

The year 1968 was a turning point in the current's history. Its membership reached 1,000 (many of whom were students), it launched the Socialist Worker newspaper, and began to transform itself into a centralized Leninist party. It also attempted to lay down roots in industry and encourage rank and file movements to challenge the moderate reformism of trade union leaders. Rank and file activity was seen as embodying the group's vision of the emancipation of the working class being brought about by the working class itself. By 1974, IS had about 4,000 members, and 40,000 copies of Socialist Worker were printed each week. In 1977, the organization became the Socialist Workers Party (SWP). ${ }^{15}$

The IMG developed out of a small entryist organization founded by Pat Jordan and the future Labour MEP Ken Coates. Despite its small size, it contributed to creating the Vietnam Solidarity Campaign. It gained increased visibility when it recruited Tariq Ali, one of the leading figures in the movement. Its members and supporters were also heavily involved in the Black Dwarf newspaper and in the New Left Review. In 1969, it left the Labour Party. It distinguished itself from other Trotskyist groups by not concentrating mainly on the industrial working class. It believed that students had revolutionary potential and that universities could become bases for opposition to capitalism. ${ }^{16}$ Its interest in young people led it to engage with youth culture. It praised the rebelliousness of the Rolling Stones, printing the lyrics of the song "Street fighting man" in Black Dwarf, and Tariq Ali courted John Lennon. ${ }^{17}$ It threw itself into numerous singleissue campaigns, as well as becoming involved in the women's movement and closely following the situation in Northern Ireland (it gave unconditional support to the 
Provisional Irish Republican Army). ${ }^{18}$ Seeing the potential for the growth of the Labour left and having failed in its efforts to unite the revolutionary left, it re-entered the Labour Party in 1982, this time as the Socialist League. ${ }^{19}$

11 Gerry Healy had been one of the dominant figures of the Revolutionary Communist Party and the Club. In 1959, he created the Socialist Labour League (SLL). Although it was almost immediately proscribed by Labour, it pursued its entryist strategy wherever it was possible to do so. It thus came to dominate the Young Socialists, Labour's youth wing, in the early 1960s. In the late 1960s and early 1970s, the actors Vanessa and Corin Redgrave became active members of the organization, while sympathizers included Ken Loach, Trevor Griffiths and Colin Welland. In 1973, the organization was renamed the WRP and began publishing the daily News Line newspaper three years later. The WRP was increasingly known for the idiosyncratic behaviour of Healy. Having previously proclaimed the imminence of an economic crisis of unprecedented proportions, he claimed in 1974 that a military dictatorship was four days away. ${ }^{20}$ Two hundred members, including activists at the British Leyland plant in Cowley, were expelled. ${ }^{21}$ In 1985, after a decade of declining influence, the WRP split several ways, when Healy was accused of sexually exploiting and raping young female members. ${ }^{22}$

The Trotskyist organization most closely wedded to the idea of working within the Labour Party was the Revolutionary Socialist League, whose origins can be traced back to the RCP. In 1964, it began to publish a newspaper entitled Militant and to use this name to refer to itself in public. By 1970, it was the main Trotskyist organization in the Labour Party, and its members were highly active in Liverpool and in the Labour Party Young Socialists (LPYS). In 1973, a member of Militant was elected to Labour's National Executive Committee as the LPYS representative. ${ }^{23}$ Between 1965 and 1975, Militant grew from 100 to 1,000 members $^{24}$, and its activities were scrutinized in a report about entryism compiled by Labour's general secretary. However, it was only in the 1980s that Militant became a significant force within the party.

Throughout its history, the radical left underwent significant changes, experiencing several splits and realignments. In the 1970s, it could be divided into two main families: the CPGB and the various Trotskyist parties which were no longer engaged in entryism. Despite their shared characteristics, they tended to be in competition with each other and rarely worked together. In terms of membership, the CPGB was larger than all the Trotskyist groups put together, although it was itself losing members and also had numerous inactive members. In spite of the relatively small number of people concerned, the radical left was highly active, and its members came to the fore in a number of different areas.

\section{Successes and failures in the 1970s}

Much of the radical left attempted to have a presence in the trade unions and in industry. The CPGB was by far the most deeply-implanted organization in the trade union movement in the 1970s, mainly as a result of the Broad Left alliances it had created with the non-Communist left. ${ }^{25}$ As early as the 1960 s, the party had supported non-Communist left-wingers in union elections, allowing Hugh Scanlon to become leader of the Amalgamated Engineering Union in 1967 and the former Communist Jack Jones to become general secretary of the Transport and General Workers Union (TGWU) in 1969. In the following years, Broad Lefts allowed Communists to be elected to leading positions 
in a number of unions. In the early 1970s, according to a historian of the CPGB, one in ten trade union officials was a member of the party and the leading bodies of most unions contained several Communists. ${ }^{26}$ For example, the executive committee of National Union of Mineworkers (NUM) had six Communists, the National Union of Railwaymen four, the Union of Post office Workers four, the Union of Construction, Allied Trades and Technicians two, and the TGWU ten. Max Morris, the president of the National Union Teachers (NUT) was a party member, as were the president of the Associated Society of Locomotive Engineers and Firemen and the general secretary of the Technical, Administrative and Supervisory Section (TASS). The CPGB also had a strong influence over the local and regional politics of some unions. For example, in the Yorkshire region of the NUM, it had thrown its weight and organizational skills behind the former Communist Arthur Scargill, allowing him to be elected to the regional leadership. ${ }^{27}$

well as participating in the leadership of many unions, the CPGB also had a grassroots presence in unions and in the workplace. A significant number of shop stewards were members of the party. The CPGB tried to bring together and mobilize militant rank and file trade union activists. Its main vehicle for doing so was the Liaison Committee for the Defence of Trade Unions (LCDTU). Founded in 1966, it had organized opposition to the Labour government's attempts to limit the influence of trade unions in the late 1960s. The CPGB was not the only force which was active in grassroots movements. In the early 1970s, the International Socialists (IS) were considerably smaller than the CPGB ${ }^{28}$, but they established a rank and file movement in the NUT and published a newspaper entitled Rank and File Teacher, whose circulation reached 9,000 in 1974. ${ }^{29}$ Other movements with their own publications were rapidly created. ${ }^{30}$

As a result of the CPGB's presence in the leadership of many unions, some of its members were active in the major industrial events of the decade and became household names. The prime example is Mick McGahey. Leader of the Scottish miners, he was also National Vice President of the NUM and pressed the union's national leader, Joe Gormley, to adopt more militant strategies. McGahey was thus an important figure in the miners' strikes of 1972 and $1974 .{ }^{31}$ He was aided by Arthur Scargill, who went on to lead the union in the 1980s. Communists also came to the fore in a number of other important disputes, particularly concerning Edward Heath's Industrial Relations Bill. In the early 1970s, the LCDTU was implacably opposed to the bill and tried to force the Trades Union Congress to adopt a militant stance, organizing demonstrations and having resolutions adopted by union branches. Half a million workers struck in support of its demands in December 1970, and three million responded to its call for a one-day general strike in March $1971 .^{32}$ Although the CPGB was unable to prevent the government from adopting the bill, its continued mobilization made it difficult for the new law to be put into practice.

Two CPGB members (Bernie Steer and Vic Turner) were among the five dock workers sentenced to prison after refusing to obey a court order to stop picketing during a dispute. Following a mass campaign organized by the LCDTU and threats of a general strike, the 'Pentonville Five' were rapidly released. In 1972, the Building Workers Charter group, including activists from the CPGB and IS, went on strike to demand higher wages and better working conditions. After the successful strike, the Communist Des Warren was one of the two building workers accused of offences linked to flying picketing in Shrewsbury and was sentenced to three years in prison. ${ }^{33}$ Communist shop stewards were prominent in a number of disputes. In 1971, the government refused to give assistance to the Upper Clyde Shipbuilders company, which was facing major financial difficulties. Led 
by shop stewards, including the Communists Jimmy Airlie and Jimmy Reid, employees embarked upon a work-in. They benefited from huge popular support and forced the government to reverse its decision. ${ }^{34}$ Derek Robinson was a leading shop steward at the Longbridge plant of British Leyland and had taken part in numerous disputes with the management of the company. In 1979, he was accused of co-authoring a pamphlet criticizing the company and advocating militant action against its plans, leading to his dismissal. During the unsuccessful campaign to reinstate him, he was branded 'Red Robbo' by sections of the tabloid press. Communists and Trotskyists also supported workers in conflicts in companies in which they had no members. Between 1976 and 1978, the CPGB and IS mobilized in solidarity with striking workers at the Grunwick film processing laboratories, for example.

The radical left was also prominent in militant opposition to the far-right National Front (NF). As well as being opposed to racism and racist violence, it saw the NF as an objective ally of the ruling class as it divided the working class, opposing white and black workers. It believed that the growing economic crisis facing Britain in the 1970s could lead to a surge of support for the extreme right among some sections of the population. However, it was divided regarding the appropriate strategy to adopt. In line with its overall strategy, the CPGB sought to create broad alliances against the NF, reaching out to representatives of the church, members of the Liberal Party, etc. IS/SWP and the IMG played a prominent role in physical confrontations with the NF. At the heart of their activities was the conviction that the NF should be prevented by any means possible from expressing its views in public. In the words of Tony Cliff, leader of IS/SWP:

Our attitude to the issue was that there should be 'No platform for fascists'! To those who argue that this is to deny democratic rights we reply that Nazism exists to destroy the democratic rights of others. It makes use of freedom to march to intimidate and deny freedom generally. Does a cancer have equal rights with a normal cell to reproduce and spread? ${ }^{35}$

Consequently, IS, the IMG and other militant anti-fascists began to disrupt National Front meetings and demonstrations.

In June 1974, a picket of an NF meeting at Red Lion Square in London, organized by the IS and the IMG, ended in violence between 2,500 demonstrators and the police. One of the protestors, Kevin Gately, was killed by the police, while 51 were arrested and 50 injured. ${ }^{36}$ In August 1977, about 5,000 demonstrators gathered in Lewisham in an attempt to prevent an NF demonstration, attacking it with bricks and bottles. Clashes with the police ended in dozens of arrests, and the march had to be abandoned. Two years later in Southall, a march organized by the Anti-Nazi League (ANL) resulted in serious clashes with the police as demonstrators tried to disrupt an NF election meeting. The ANL had been founded in 1977 in the aftermath of the Lewisham incidents as the SWP sought to avoid isolation and mobilize the labour movement as a whole. It attracted the support of Labour MPs, including future party leader Neil Kinnock, and trade unions. SWP and ANL member Blair Peach was killed by the police during the fighting in Southall, many were injured and over 700 arrests were made. ${ }^{37}$ Although individual Communists took part in militant anti-fascist activities and the party itself eventually supported the ANL, the CPGB opposed the use of violence. In Lewisham, for example, it had had a hand in organizing a peaceful demonstration at a different time of the day and at a different location to the NF march. In addition to providing physical opposition to the FN, the ANL engaged in more traditional forms of action. Between 1977 and 1979, it distributed about 9 million leaflets 
and sold 750,000 badges. Approximately 250 ANL branches were created, and between 40,000 and 50,000 people joined the movement. ${ }^{38}$

Violent actions were heavily reported in the press and were given overwhelmingly negative coverage. After the Lewisham demonstration, the Daily Mirror accused antifascists of being as objectionable as the National Front ${ }^{39}$, while according to the Daily Mail and the Daily Express, they were even "nastier" and were denounced as "red fascists". ${ }^{40}$ The events in Southall in 1979 gave rise to similar reactions. The Daily Mail's front-page headline screamed "Extremists go to War on Police", while a three-page article referred to " left-wing extremists" using "sophisticated street-fighting tactics". ${ }^{41}$ Sections of the labour movement were also highly critical. For example, Sid Bidwell, MP for Southall, stated, "I have no time for hooligans [in the NF] ... and for those crackpot adventurers who have yet to take their part in the real Labour movement. We cannot counter them by a strategy of trying to outthug the thugs of the National Front." ${ }^{\prime 2}$ According to Deputy Prime Minister Michael Foot, " You don't stop the Nazis by throwing bottles or bashing the police. The most ineffective way of fighting fascists is to behave like them."

However, members of IS/SWP were also instrumental in promoting innovative forms of opposition to the far right, which received more positive coverage. In 1976, several music fans sent a letter to the British music press to protest against racist comments made by the guitarist Eric Clapton at a concert in Birmingham. The authors of the letter included Roger Huddle of IS and Red Saunders who was an IS sympathizer. The letter received a great deal of support, and several months later Rock Against Racism (RAR) was founded to mobilize young people against racism in the music business and against the $\mathrm{NF} .{ }^{43}$ It organized scores of concerts throughout the country, often featuring punk and reggae bands, whose joint presence symbolized racial unity. RAR co-organized two national carnivals with the ANL in 1978. The Clash, Steel Pulse and the Tom Robinson Band performed at the first, which attracted 80,000 people, while Elvis Costello, Stiff Little Fingers and Aswad played at the second in front of 100,000 people. Before the 1979 general election, RAR mounted a tour of constituencies where NF candidates seemed poised to receive a high number of votes. The SWP gave practical assistance to RAR, lending it an office, allowing it to use the party's printing facilities and covering its activities in Socialist Worker ${ }^{44}$ Moreover, its members were highly active in both RAR and the ANL, providing the organizational backbone of both movements.

The radical left was central to a number of other extra-parliamentary campaigns. In 1973, members of IS, the IMG, the CPGB and various smaller groups founded the Troops Out Movement, which campaigned for an end to the British military presence in Northern Ireland. Communists in particular were heavily involved in the Chile Solidarity Campaign after Augusto Pinochet overthrew Salvador Allende's Popular Unity government in 1973. The radical left was the main source of opposition to Queen Elizabeth's Silver Jubilee celebrations in 1977. The SWP produced a Stuff the Jubilee badge and organized a series of concerts, while the CPGB put on an event at the Alexandra Palace in London entitled the People's Jubilee. The event, which was intended as a celebration of the lives of ordinary working people and included music, dance and theatre, attracted over 10,000 people and caught the attention of the mainstream press. ${ }^{45}$ The SWP mounted the Right to Work Campaign and organized a series of marches against unemployment, while the WRP mounted protests against rising unemployment, organizing a rally in 1972 which attracted over 8,000 people. ${ }^{46}$ Finally, unlike the mainstream of the labour movement, 
much of the radical left was receptive to demands for gay rights, and some activists became involved in the Gay Liberation Front. ${ }^{47}$

During the 1970s, the radical left participated in traditional strategies such as strikes and demonstrations to put pressure on the government and employers, but it also innovated with work-ins and music-based activities. Despite the numerical decline of the CPGB, Communists were able to influence disputes due to their prominent positions in trade unions and their ability to mobilize workers. Trotskyists stepped into areas vacated by the CPGB, such as militant anti-fascism and, to a certain extent, rank and file activism. The radical left had greater visibility than in previous (or later) decades, helping to shape events rather than simply observing them. In the words of the historian Willie Thompson, who had been a party member: "[w]ith all necessary caution allowed for, it is highly likely that if the Communist Party had [...]disintegrated after 1956, the outcome of the years 1970-3 would have been markedly different". ${ }^{48}$ The CPGB had given direction to the growing working-class militancy of the early 1970s that it had helped to create. Ironically, the actions of the CPGB also contributed to changing the balance of forces in the Conservative Party. Margaret Thatcher later admitted that the Heath government's Uturn over the Upper Clyde Shipbuilders and its defeat in the 1972 miners' strike made her question the overall direction of the government and reflect on her own political future. ${ }^{49}$ Historian and activist Dave Renton has written that "without the League, the National Front's organization would have continued and prospered". ${ }^{50}$ Nevertheless, the foundations on which the radical left built its relative success were weaker than may seem apparent at first sight.

Despite the CPGB's strength in the trade union movement, it only controlled the leadership of one union - TASS. In the leading bodies of all other unions, Communists were in a minority and owed their very presence to the Broad Left alliances with the nonCommunist left. As a result, it was difficult for Communists to act on their own and put forward the specificities of their party's positions too strongly. They tended to subsume differences of opinion and simply advocate unity of the left. The weakness of the party's situation became clear when its erstwhile allies Jack Jones and Hugh Scanlon supported the Labour government's policy to limit wage increases and thus divided the left. By opposing the Social Contract ${ }^{51}$, the CPGB publicly distanced itself from them, breaking with the Broad Left strategy it had followed for several years. It was unable to fall back on a more independent strategy based on the LCDTU since the party's grassroots presence had been weakened by the fall in the number of its members and of its factory branches. ${ }^{52}$ Although IS/SWP had tried to develop rank and file organization, its areas of influence were relatively limited. Significantly, both parties played a very minor role in the Winter of Discontent of 1978/79.

In the 1970s, the main strength of the CPGB had been its influence in the labour movement, where it appealed to activists and acted as a pressure group, trying to push it further to the left. However, it was unable to transform the support its members received in union elections, for example, into support for the party in political elections outside the workplace. Contesting elections had never been a central aspect of the CPGB's strategy. In its early years, it had advocated a Soviet-style revolution, believing that real power was in the hands of capitalists and not in parliament. It occasionally stood candidates, seeing election campaigns as a means of strengthening the public profile of the party and gaining new recruits. As it developed its long-term programme, the BRS, it increasingly stressed the aim of having a group of Communist MPs and diverted more 
resources to election campaigns..$^{53}$ This trend was not without its critics as some Communists believed that it was a demoralizing waste of time, which contradicted its aim of closer unity with the non-Communist left. The party had lost its last two seats in parliament in 1950, and since then the Communist vote in general elections had fallen regularly. By 1970, it was increasingly unusual for a Communist candidate to receive more than a thousand votes or to gain more than $2.5 \%$ of the total vote in a particular constituency. It was hoped that the party might be able to benefit from the publicity that its shop stewards had received as a result of their prominent position in a number of campaigns. In the two general elections of 1974, it stood Jimmy Reid, one of the leading figures of the work-in at the Upper Clyde Shipbuilders, in the Central Dunbartonshire constituency. Reid was also one of four Communist local councillors in Clydebank. He received nearly 6,000 votes (over 14\%) in February 1974 and 3,400 votes (8.7\%) in October. ${ }^{54}$ Although these results were the best performances in a general election by a Communist since the 1950 s and were significantly higher than all the other CPGB candidates, Reid finished far behind the Labour candidate. ${ }^{55}$ Derek Robinson was another well-known Communist candidate. Yet he received only a few hundred votes in both elections, less than one percent of the total vote in his constituency in Birmingham. In spite of its activism in trade unions and in industry, the CPGB was unable to make an electoral breakthrough.

Although IS/SWP had been behind the success of RAR and the ANL, both of which had gone beyond the traditional confines of the labour movement and taken anti-fascism to a new audience, it was unable to capitalize on this. When it was widely believed that the NF had been thoroughly marginalized, activists and sympathizers drifted away. RAR and ANL were thus victims of their own success. IS/SWP also faced similar problems to the CPGB when it ventured into electoral politics. In 1976, IS decided to start contesting byelections. It had two aims: "firstly, to offer a generalized political alternative to a small layer of people looking for something to the left of the increasingly discredited Labour Government: secondly, to use the opportunity for propaganda to build a local branch of the organization" ${ }^{56}$ Its first test was the Walsall North by-election of the same year. It received less than six hundred votes (just under $1.6 \%$ of the votes cast). Although it admitted that this result was "not startlingly good", it tried to take heart from the fact that it was higher than the CPGB's result in the same constituency in the October 1974 general election and 25 new recruits were made. ${ }^{57}$ However, it was not until the late 1990s that the SWP stood candidates again. The IMG also began to take an interest in standing in elections. Although it attempted to rally other sections of the radical left under the Socialist Unity banner, only small groups responded. Consequently, in some constituencies, Socialist Unity candidates faced the SWP or the CPGB. Although Socialist Unity tended to poll more votes than its rivals, its results were not significantly better. ${ }^{58}$ Facing its usual problems of limited access to the mainstream media, an unfavourable electoral system and its own sectarian tendencies, the radical left as a whole was unable to benefit from its general prominence and improve its position in elections in the 1970s.

\section{Conclusion}

With the benefit of hindsight, the 1970s were almost a golden age for the radical left. Buoyed by the industrial militancy of the early 1970s and the cultural changes of the mid to late 1970s, it was a significant feature of British politics and a force to be reckoned 
with. However, the limits of its power and influence were already apparent and became even more so in the 1980s. The combination of industrial decline, anti-trade union legislation and mass unemployment weakened it further, while the rise of the Labour left appeared to offer an alternative pole of attraction to activists and to some organizations such as the IMG. The most influential radical left grouping was the entryist organization Militant. ${ }^{59}$ Although it had fewer members than the CPGB in the 1970s, it managed to control Liverpool local council and had three MPs elected in 1987, before its leading figures were expelled. By the end of the 1980s, most of the radical left was again outside the Labour Party but in a considerably more hostile climate than previously.

Jeremy Tranmer is a senior lecturer at the Université de Lorraine, where he teaches contemporary British history, politics and popular culture. He wrote his $\mathrm{PhD}$ about British Communism in the 1970s and 1980s and has published numerous articles about the radical left. He is also interested in the relationship between the left and popular music

\section{BIBLIOGRAPHY}

ALI, Tariq. Street Fighting Years. An Autobiography of the Sixties. London: Verso, 2005.

ANDREWS, Geoff. Endgames and New Times. The Final Years of British Communism. 1964-1991, London: Lawrence \& Wishart, 2004.

CALLAGHAN, John. The Far Left in British Politics. Oxford: Blackwell, 1987.

CLIFF, Tony. A world to win. Life of a revolutionary. London, Bookmarks, 2000.

COMMUNIST PARTY OF GREAT BRITAIN. The British Road to Socialism. London: CPGB, 1978.

COATES, David and JOHNSTON, Gordon. Socialist Strategies. London: Martin Robertson \& Company Ltd, 1983.

DARLINGTON, Ralph and LYDDON, Dave. Glorious Summer. Class struggle in Britain, 1972. London: Bookmarks, 2001.

FYRTH, Jim (ed). Britain, Fascism and the Popular Front. London: Lawrence \& Wishart, 1985.

SMITH, Evan and WORLEY, Matthew (eds). Against the Grain. The British far left from 1956, Manchester: Manchester University Press, 2014.

ROWBOTHAM, Sheila. Promise of a Dream. Remembering the Sixties. London: Verso, 2001.

TAAFE Peter, The Rise of Militant - Militant's 30 years. London: Militant Publications, 1995.

THOMPSON, Willie. The Good Old Cause. British Communism 1920-1991. London: Pluto Press, 1992.

THOMPSON, Willie and HART, Finlay. The UCS Work-in. London: Lawrence \& Wishart, 1972.

THORNETT, Alan. Inside Cowley. Trade union struggle in the 1970s: who really opened the door to the Tory onslaught? London: Porcupine Press, 1998. 
TRANMER, Jeremy, "Rocking Against Racism: Trotskyism, Communism and Punk in Britain", in Robert Adlington (ed), Red Strains. Music and Communism outside the Communist Bloc, Oxford: Oxford University Press, 2013, pp. 267-281.

\section{NOTES}

1. Decca Aitkenhead, “I want to hug him but also shout at him': Tom Watson on Jeremy Corbyn", Guardian, 9 August 2016, http://www.theguardian.com/politics/2016/aug/09/ tom-watson-interview-jeremy-corbyn-labour-rifts-hug-shout consulted 26 August 2016.

2. For examples concerning the Communist Party of Great Britain, see Graham Mather, Communist Party of Great Britain: Freedom's Foremost Enemy, London: Aims of Industry, 1978, as well as Francis Beckett, Enemy Within. The Rise and Fall of the British Communist Party, London: John Murray, 1995, pp. 177-180. For the radical left in general, see Blake Baker, The Far Left. An Exposé of the Extreme Left in Britain, Worthing: Littlehampton Book Services, 1981. Baker was a journalist at the Daily Telegraph.

3. Willie Thompson, The Good Old Cause. British Communism 1920-1991, London: Pluto Press, 1992, p. 160.

4. Maoism had appeared in Britain when the Communist Reg Birch founded the Communist Party of Britain (Marxist-Leninist) in 1968, although there was already some interest in the Cultural Revolution in China. However, by the 1970s, Maoism had become extremely marginal, even by the standards of the radical left.

5. Jim Fyrth, Britain, Fascism and the Popular Front, London: Lawrence \& Wishart, 1985.

6. For an analysis of the CPGB's changing positions, see Kevin Morgan, Against Fascism and War: Ruptures and Continuities in British Communist Politics, 1935-1941, Manchester: MUP, 1989. All membership figures in the following pages are taken from Willie Thompson, The Good Old Cause, p. 218.

7. Ironically, it was revealed by a former leading figure in the party in 1991 that Stalin himself had written certain passages of the first BRS. George Matthews, "Stalin's British Road", Changes, 14 September 1991, pp. 5-7.

8. In the 1970s, one of the main signs of the closer links between the CPGB and the Labour left was the debate over the Alternative Economic Strategy, a series of radical proposals developed by economists from both parties. The basic proposals can be found in Michael Bleanet, “Alternative Economic Strategy”, Comment, 15 April 1978, pp. 115-116.

9. Surrey District Committee, "Revisionism of Marxism-Leninism", Comment, 30 April 1977, p. 146.

10. For a presentation of these divisions, see Nina Fishman, "The British Road is Resurfaced for New Times: From the British Communist Party to the Democratic Left", in Martin J. Bull and Paul Heywood (eds), West European Communist Parties after the Revolutions of 1989, London: St Martin Press, 1994, pp. 145-177. The CPGB was succeeded by Democratic Left, which, after two changes of name, merged with Charter 88 to form Unlock Democracy. Several organisations claim the mantle of the CPGB. The most significant of them is the Communist Party of Britain, which continues to have a close relationship with the Morning Star.

11. John Callaghan, The Far Left in British Politics, Oxford: Blackwell, 1987, p. 57. 
12. The Fourth International was created by followers of Leon Trotsky in 1938 after his expulsion from the Soviet Union and signaled the recognition that it was impossible to change from within the Soviet-dominated Third International or Communist International (Comintern).

13. Evan Smith and Matthew Worley, "Introduction. The far left in Britain from 1956", in Evan Smith and Matthew Worley (eds), Against the grain: The British far left from 1956, Manchester: MUP, 2014, p. 3.

14. Tony Cliff, A world to win. Life of a revolutionary, London: Bookmarks, 2000, pp. 39-49.

15. The SWP became more visible as the CPGB declined in the 1980s, dominating many extra-parliamentary campaigns. It grew in the 1990s and early 2000s, and it helped to found the Stop the War Coalition against the war in Iraq. In more recent years, it has been dogged by infighting. Its participation in George Galloway's Respect proved to be divisive and contributed to the demotion in 2009 of John Rees, a prominent figure in the party leadership who was also the national secretary of Respect. He resigned from the SWP the following year. In 2013, the SWP's conference was dominated by accusations of rape made against a former leading member of the Central Committee and by discussion of how the party's leadership had dealt with them. Critics of the leadership were defeated at a special conference held in March 2014.

16. Sheila Rowbotham, Promise of a Dream. Remembering the Sixties, London: Verso, 2001, p. 191.

17. Tariq Ali, Street Fighting Years. An Autobiography of the Sixties, London: Verso, 2005, pp. 330-335, 361-380.

18. Ibid., p. 314.

19. Tariq Ali, the most high-profile figure in the IMG, was not, however, allowed to join by Labour's National Executive Committee. The Socialist League began to fragment following the defeat of the miners' strike in 1985, and a number of splits and changes of name occurred in the following years.

20. David Coates and Gordon Johnston, Socialist Strategies, London: Martin Robertson \& Company Ltd, 1983, pp. 174-175.

21. Alan Thornett, Inside Cowley. Trade union struggle in the 1970s: who really opened the door to the Tory onslaught?, London: Porcupine Press, 1998, pp. 84-87.

22. Callaghan, The Far Left in British Politics, p. 81.

23. Peter Taafe, The Rise of Militant - Militant's 30 Years, London: Militant Publications, 1995, pp. 74-75.

24. Callaghan, The Far Left in British Politics, p. 205.

25. One of the key architects of the CPGB's trade union strategy was the party's Industrial Organizer Bert Ramelson. Occasionally dubbed 'the most powerful in Britain' by the tabloid press, he passed on instructions on resolutions and votes ('Needs of the Hour') to Communist delegates before trade union conferences in order to maximize their influence.

26. Geoff Andrews, Endgames and New Times. The Final Years of British Communism, 1964-1991, London: Lawrence \& Wishart, 2004, p. 116. Communist were also part of the leadership of the National Union of Students due to the alliances they had established. 
27. For an account of the rise of Scargill written by his closest Communist ally in Yorkshire, see Frank Watters, Being Frank. The Memoirs of Frank Watters, Barnsley: Monkspring Publications, 1992.

28. It is revealing that an LCDTU conference in 1970 attracted 1,750 delegates, while only 250 people attended an IS industrial conference held the following year. Chris Harman, The Fire Last Time: 1968 and After, London: Bookmarks, 1988, pp. 237-238.

29. Callaghan, The Far Left in British Politics, p. 98-99.

30. Cliff, $A$ world to win, p. 110.

31. It was later revealed that Gormley had denounced left-wing members of the NUM's executive to Special Branch. Richard Norton-Taylor, "Gormley and Buckton named as special branch informers", Gormley also remained president of the NUM long enough so that, according to the union's rules, McGahey would be too old to replace him.

32. Thompson, The Good Old Cause, p. 158.

33. For his version of events, see Des Warren, The Key to my Cell, London: New Park Publications, 1982.

34. For a sympathetic in-depth account, see Willie Thompson and Finlay Hart, The UCS Work-in, London: Lawrence \& Wishart, 1972. For a similarly sympathetic account of all the major strike activity of 1972, see Ralph Darlington and Dave Lyddon, Glorious Summer. Class Struggle in Britain, 1972, London: Bookmarks, 2001.

35. Cliff, A world to win pp. 160-161.

36. Nigel Copsey, Anti-Fascism in Britain, Basingstoke: Palgrave Macmillan, 2000, p. 120.

37. Dave Renton, When we touched the sky. The Anti-Nazi League 1977-1981, London: Pluto Press, 2006, pp. 136-155.

38. Ibid, p. 175.

39. Renton, When we touched the sky, p. 69.

40. Copsey Anti-Fascism in Britain, pp. 129-229.

41. Daily Mail Reporters, "Extremists go to War on Police", Daily Mail, 24 April 1979, pp. $1-3$.

42. This and the following examples are taken from Cliff, $A$ world to win, pp. 161-162.

43. For a history of RAR written by one of its activists, see David Widgery, Beating Time. Riot'n'Race'n'Rock'n'Roll, London: Chatto, 1986.

44. Sections of the SWP were of the opinion that punk was a genuine expression of the anger of working class young people, and Socialist Worker took a close interest in it, publishing numerous articles about it from the middle to the end of the 1970s. Jeremy Tranmer, "Rocking Against Racism: Trotskyism, Communism and Punk in Britain", in Robert Adlington (ed), Red Strains. Music and Communism outside the Communist Bloc, Oxford: Oxford University Press, 2013, pp. 272-274.

45. Michael Hornswell, “Alternative Jubilee casts a warm red glow", Times, 20 June 1977, p. 1.

46. Callaghan, The Far Left in British Politics, p. 79.

47. Lucy Robinson, Gay men and the Left in post-war Britain. How the personal got political, Manchester: MUP, 2011 (2007), pp. 93-122.

48. Thompson, The Good Old Cause, pp 158-159. 
49. Stuart Ball and Anthony Seldon (eds), The Heath Government 1970-1974. A Reappraisal, London: Routledge, 2013, pp. 151-152

50. Renton, When we touched the sky, p. 176. He also admits that other factors came into play such as the drift to the right of the Conservatives under Margaret Thatcher.

51. Bert Ramelson, The Social Contract. Cure-all or con-track?, London: CPGB, 1975.

52. By 1978, it only possessed 26 factory branches. Andrews, Endgames and New Times, p. 190.

53. See for example, Reuben Falber, "A new political phase", Comment, 28 May 1977, pp. 171-172.

54. The difference between the two results can no doubt be explained by the close result of the February election and the desire of some left-wing voters to ensure that Labour had a clear majority in parliament.

55. He left the party shortly afterwards, but the CPGB candidate in Central Dunbartonshire in 1979 polled only 1,017 votes, underlining the popularity of Reid. The results are taken from "CP general election results", Comment, 26 May 1979, p. 168.

56. Ian Birchall, Building the "Smallest Mass Party in the World", London: SWP, 1981. https://www.marxists.org/history/etol/writers/birchall/1981/smallest/part3.html consulted 15 July 2016.

57. Ibid.

58. Callaghan, The Far Left in British Politics, p. 158 and p. 185.

59. For an inside account of the history of Militant, see Peter Taafe, The Rise of Militant Militant's 30 years, London: Militant Publications, 1995.

\section{ABSTRACTS}

The radical left has been a permanent, albeit marginal, feature of British politics since the Russian Revolution. It has rarely been a threat to the Labour Party or the mainstream of the trade union movement. The 1970s are a partial exception to this general trend. Communist and Trotskyist organisations played a prominent role in industrial disputes and the fight against the extreme right. However, their influence was short-lived and limited to a certain number of precise areas, and they were unable to establish themselves electorally.

La gauche radicale constitue un élément constant, quoique marginal, du paysage politique britannique depuis la Révolution russe. Elle a rarement troublé le parti travailliste et les courants majoritaires du mouvement syndical. Les années 1970 représentent une exception partielle à cette tendance générale. Des organisations qui se réclamaient du communisme et du trotskisme jouaient un rôle de premier plan dans des luttes syndicales et dans le combat contre l'extrême droite. Cependant, leur influence était éphémère et limitée à des domaines bien précis, et elles n'arrivaient pas à s'implanter électoralement. 
INDEX

Mots-clés: gauche révolutionnaire, gauche radicale, années 1970, CPGB, SWP, Militant

Keywords: revolutionary left, radical left, CPGB, SWP, Militant tendency, 1970s

\section{AUTHOR}

JEREMY TRANMER

Université de Lorraine 